1st International Conference - Global Ethics - Key of Sustainability (GEKoS) | May 15th, 2020 | Bucharest, Romania

\title{
Meta-Analysis of the Determinant Factors in the Implementation of Integrated Reporting
}

\author{
Cristina Gabriela COSMULESE
}

https://doi.org/10.18662/lumproc/gekos2020/13

How to cite: Cosmulese, C.G. (2020). Meta-Analysis of the Determinant Factors in the Implementation of Integrated Reporting. In A. Grigorescu \& V. Radu (vol. ed.), Lumen Proceedings: Vol. 11. 1st International Conference Global Ethics - Key of Sustainability (GEKoS) (pp. 117-128). Iasi, Romania: LUMEN Publishing House. https://doi.org/10.18662/lumproc/gekos2020/13 


\title{
Meta-Analysis of the Determinant Factors in the Implementation of Integrated Reporting
}

\author{
Cristina Gabriela COSMULESE ${ }^{1 *}$
}

Abstract

The purpose of this article is to conduct a brief meta-analysis on the topic of integrated reporting (IR) in order to identify and highlight the main criticisms of this process. The main objective of the research concerned the study of specialised paper before and after the development and application of a conceptual framework regarding integrated reporting. In this respect, a few indexed papers in the ISI Web of Science will be analysed first and the meta-analysis will be performed using the cluster method. The results of the research will be a starting point for other research papers, in order to improve/perfect the economic-financial communication of the reporting entities and also in order to cover the deficiencies regarding the standardisation of IR.

Keywords: Integrated reporting; meta-analysis; economic-financial communication; standardization.

\footnotetext{
1 Assistant professor PhD. at "Ştefan cel Mare University", Suceava, Romania, e-mail: gabriela.cosmulese@usm.ro

* Corresponding author:

(C) The Authors, LUMEN Conference Center \& LUMEN Proceedings.

Selection and peer-review under responsibility of the Organizing Committee of the conference
} 


\section{Introduction}

Currently, stakeholders are increasingly interested in how companies respect the rules and principles imposed by an ethical and transparent behavior towards the environment and society. Stakeholder pressure on companies has led them to take on certain social, environmental and financial responsibilities, providing more and more information about performance from these three perspectives. In this context, the issue has been raised that traditional financial reporting is not sufficient, in the sense that it does not reveal a complete picture or does not provide enough information on the economic, social and environmental performance of an entity. This has led, over time, to the development of other types of reports that meet the information needs of users [1], [2], [3].Thus, the concept of integrated reporting appeared, which managed to arouse the interest of companies aware of the importance of social responsibility and which was adopted in practice even before this concept gained significance. The purpose of this article is to conduct a brief meta-analysis on the topic of integrated reporting (IR) in order to identify and highlight the main criticisms of this process.

\section{The importance of Integrated Reporting for internal decision making}

At present, the company's stakeholders are no longer interested solely in the company's future, but also in a multitude of groups that as a whole group sustain ethical, social and environmental issues. Thus, the companies are geared towards their business' efficiency, effectiveness and sustainability. Consequently, the sustainable development, the business ethics, the social responsibility and the critical consumption have a top priority for the management of any type of business as the businesses' sustainability do not depend only on their economic and financial performance, but also on the way that specific company is capable to manage the sustainability of its activity.

The development of the latest technologies allowed for the time and space reduction based on conveying information thus making a tighter connection between the consumer and the companies by making them aware of what lies behind the consumer's choices as well as by undermining the price/quality relationship when valuing the products/services.

At the same time, the latest technologies allow the companies the chance of improving their social impact of their activities. 
In this new context, it is vital for companies to redefine their options by including their commitment to the social responsibility, too. Moreover, it is important that these companies reveal the way they fulfil their social dories by making use of those tools that are able to guarantee the stakeholders the reliability and transparency. Thus, the Integrated Reporting represents the most suitable accountability method in regards to establishing a optimal dialogue with the stakeholders. This fact reveals the company's concern of satisfying their interests in the highest degree possible based on a direct access to their data base and clear information by avoiding the specific interpretation difficulties of those financial reporting information.

However, the present-day financial reporting systems as well as the sustainability reporting systems fail to offer those information that are necessary for the environment and the society itself to deal with. This is the reason why in 1997 the Global Reporting Initiative (GRI)[4] was regarded both as a multi-stakeholders process and an independent organization.

The aim of this organization is to support the companies, the public administrations and other organizations understand and disclose the impact of their activity on those issues related to the sustainable development such as: the climate changes, the human rights, corruption and other social issues. The model that is promoted by the GRI refers to a reference parameter that is valid for all the companies. It provides a rather flexible structure that comprises certain core indicators (e.g. the air emissions related to safety etc.) which need to be shown in connection with those companies using them regardless of the field of activity they operate in. In contrast, in order to provide an explanatory and coherent image for each and every field and activity, it is necessary to make use of extra reporting indicators. The GRI trends refer to a methodology focussing on a self-evaluation approach that is structured based on the triple bottom line as the indicators are grouped on the main impact economic, environmental and social domains.

Thus, the main sustainability reporting trends refer to:

a) The trends referring to the structure of the reporting, the identification of the reporting contents and the insurance of the quality of the disclosed information that are attributed to the materiality reporting, including the stakeholders, the sustainability and accessibility, the balance, comparability, accuracy, opportunity, credibility and clarity;

b) A standard briefing of the communication including the performance's strategy and typology, the management methods and the main economic, environmental and social performance indicators that enable the estimation of the sectorial interdependence relationship (i.e. the KPI key performance indicators). 
In 2009, the GRI [5], in collaboration with other international organizations such as The Accounting for Sustainability Project (A4S), The International Federation of Accountants (IFAC) and The International Accounting Standard Board (IASB) suggested for the first time the design of a unique, global and integrated reporting document that exceeded the stage of the isolated financial reports and the common reporting of the financial results (that were done only under the form of yearly consolidated or individual reportings up to then), the environmental, social and governance results (that were reported separately according to the options of the companies' management in terms of the non-financial and voluntary reporting) [6,7]. When the idea of encouraging the companies' business sustainability has started taking shape, the GRI's principles became an international priority. As shown in the study's introductory part, the IR is the result of both the companies' management and the stakeholders' need of contributing to the change in the communication between these two parties, especially in terms of the performance that has been taken into account not only from certain stakeholders' point of view, but also for all the stakeholders as such. These kind of relationships that are established between the company and different kinds of categories of stakeholders adds value to the company itself and formulates the so-called stakeholders' theory. Later on, once the Social Corporate Responsibility (SCR) issue was introduced, other company's new communication tools with the outside world have appeared in regards to the disclosure of extra information based on the environmental, social, social and ecological, sustainable report. These are the documents that are different from the mandatory annual financial reporting. They have been specifically created as the companies' answer to the pressure of the external stakeholders that need to be sure that they will be able to operate in socially legit conditions. The CSR actually refer to the integration of the ethical aspects in the the corporate strategic point of view [8]. A responsible corporate behavior towards the stakeholders refers to the companies' tendency of managing the ethical and social impact issues within the fields of activity they operate in. This is the reason why the CSR is viewed as a management and governing model that was designed specifically for satisfying the stakeholders' demand, for fulfilling its legal duties and for promoting an ethical business behavior. The CSR's implementation requires the involvement of all the company's management fields in order to sustain the strategic and organisational policies. Later on, as a result of these changings, the development of several proposals of different regulating bodies and standard setters will take place. They made use of several hererogenous approaches as a result of being incapable of fully satisfying the stakeholders' information demands based on a single report. 
Thus, starting with 2015, the gradual implementation in the European countries of the latest European rules has required the corporations to submit, together with their financial reportings, a nonfinancial reporting in order to explain the steps they took in their field of activity in order to protect the environment and to ensure an accurate personnel's management so that they will guarantee the oversee of the human rights and the fight against corruption. This type of document needs to be designed by the administration council and needs to be audited the same way as for the financial reportings. The economic doctrine does not refer to a clear distinction between the concept of financial information (regarded as mandatory) and the non-financial information (i.e. the voluntary one). This aspect is due to the fact that the regulation of this type of reporting varies from one country to another. In other words, it depends on the country the reporting company operates in and, consequently, the laws change as a result of the existence of certain economic and financial factors as well as the possibilities to voluntarily adopt or not those information that have to do with the qualitative aspects. Having in view this scenario, one of the most significant challenges for the professionals is finding a means to incorporate the sustainability within this complex corporate reporting by using the IIRC guidelines as well as by making use of the experience of those who have already used and invested in this approach.

\section{Short review of empirical study}

As Onida [9] stated, a company's creation or the rise of its value stands for an enriched wellbeing of all those individuals that are directly or indirectly related to it as well as the highest performance throughout a certain moment, a period of time, a specific place, as well as its asset. Thus, one makes the conscious voluntary transition from the social corporate responsibility to the mandatory one that has been regulated by law that, so far, has been stipulated especially for the listed companies, banks, insurance companies (i.e. the so-called public interest entities). In their case, the new requirement refers to those companies that have at least 500 employees. At the end of the fiscal year, these companies tend to exceed at least one of the following requirements: the overall asset is over 20 million euros or the turnover is above 40 million euros. This becomes an interesting challenge for the companies due to the fact that the investors are more and more interested in those companies that have a higher sustainability rate. It is estimated that $30 \%$ of the total managed assets worldwide are the 
"responsible" and "sustainable" types of investments, while the Impact Investment types have reached the value of 60 billion dollars [10].

In fact, the IR is an extra step in the reporting field and an evolution of the sustainable relationship (or the social or environmental balance sheet) that has been designed in order to highlight the environmental, social and governance variables (i.e. the so-called ESG variable) that are part of the statutory financial reports. The novelty of the IR refers to the existence of the financial and non-financial information that are not only the result of a simple adding up, but, on the contrary, a result of the union and their combination in a single report. This unitary representation allows the emphasis of the relationship between the financial and non-financial information that have been discussed as separate entities so far. In other words, the IR provides a new bird's eye view on the company as it is able to highlight the synergy resulting from this informational inclusion that leads to the creation of added value for the company.

As far as the IR's advantages or the benefits are concerned, they have been largely discussed by Gasperini [11] who identifies, based on the feedback of those companies that chose to be part of the IIRC group, a series of benefits and critical issues in regards to the corporate implementation of the integrated thinking process which means the managerial culture of the reporting entity. It characterizes the management and the company's ability of thinking in an integrated manner [12]. This report also highlights the main advantages of using the IR such as: the improvement of the quality of the information that are available on the market by ensuring a more efficient allotment of the financial resources; the promotion and the coherent approach of the corporate reporting that is based on identifying and disclosing those factors that influence the company's ability of creating value; the embedding of an integrated logics within the business decision-making process in order to provide a holistic perspective of the company itself in regards to its activity, its risks and opportunities that enable it to make use of a sustainable management that is geared towards creating value in time.

There are also authors like Cosmulese et al. [13] who believe that theIR plays a key role in minimizing the informational asymmetry due to the way it manages to include a series of diverse types of information that are helpful in satisfying the stakeholders' requirements.

Following a brief review of the literature on integrated reporting, I have generally noted the following future research directions (Figure 1): 


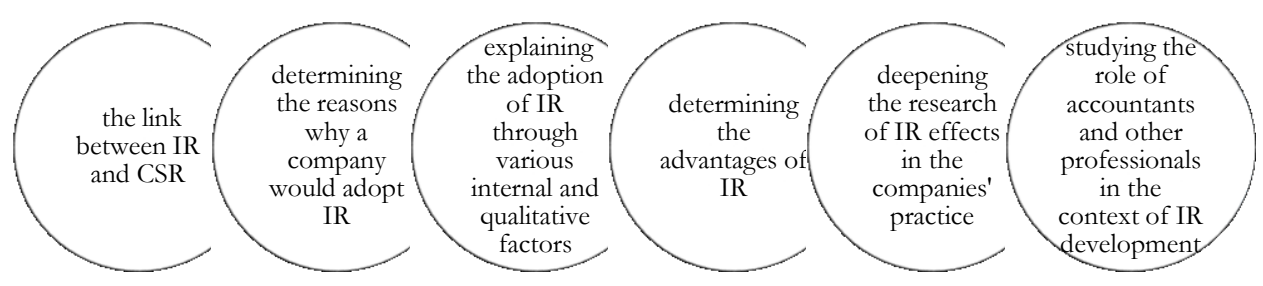

Figure 1. Organization's business model

Source: Own elaboration

Next, I will to provide a brief analysis of the latest scientific studies whose results have shown and confirmed the advantages of the IR and the means that can be used in order to improve the relationships between the stakeholders and the reporting companies. Initially, I set out to study about 50 articles, but I stopped at a number of 20 , taking into account only the most recent 2018, 2019 (see Table 1).

Table 1. Literature review - research on integrated reporting

\begin{tabular}{|c|c|c|c|c|}
\hline Authors & $\begin{array}{l}\text { Research } \\
\text { purpose }\end{array}$ & Sample & Findings & Utility \\
\hline $\begin{array}{l}\text { Roman, } \\
\text { Mocanu \& } \\
\text { Hoinaru [14] }\end{array}$ & $\begin{array}{l}\text { The study } \\
\text { investigates the } \\
\text { determinants of } \\
\text { legibility and } \\
\text { confidence } \\
\text { which shape the } \\
\text { divulgation style } \\
\text { of integrated } \\
\text { reports }\end{array}$ & $\begin{array}{l}\text { Sample is } \\
\text { compose out of } \\
\text { thirty annual } \\
\text { reports draw } \\
\text { randomly from } \\
\text { the IR } \\
\text { examples } \\
\text { database }\end{array}$ & $\begin{array}{l}\text { Results show } \\
\text { that the higher } \\
\text { the incomes of } \\
\text { the reporting } \\
\text { entities, the } \\
\text { more equaled, } \\
\text { their IR is, } \\
\text { while } \\
\text { immature } \\
\text { entities use a } \\
\text { more } \\
\text { optimistic tone } \\
\text { at the time of } \\
\text { reporting. }\end{array}$ & $\begin{array}{l}\text { The study may } \\
\text { be useful in } \\
\text { assessing } \\
\text { whether IR } \\
\text { mandating } \\
\text { increases the } \\
\text { disclosure } \\
\text { features and } \\
\text { whether South } \\
\text { African firms } \\
\text { have obtain } \\
\text { better curtness, } \\
\text { and stability in } \\
\text { reporting }\end{array}$ \\
\hline $\begin{array}{l}\text { Beretta, } \\
\text { Demartini, \& } \\
\text { Trucco [15] }\end{array}$ & \begin{tabular}{|l|} 
The study \\
investigates how \\
the content and \\
semantic \\
properties of \\
intellectual \\
capital disclosure
\end{tabular} & $\begin{array}{l}\text { All reports by } \\
\text { European listed } \\
\text { companies } \\
\text { from } 2011 \text { to } \\
2016 \text { disposable } \\
\text { via the IR }\end{array}$ & \begin{tabular}{|l|} 
Results suggest \\
that entities \\
who divulgates \\
a big amount \\
of diluted \\
information \\
concerning
\end{tabular} & $\begin{array}{l}\text { The results of the } \\
\text { study may be } \\
\text { useful to analysts } \\
\text { and investors in } \\
\text { providing them } \\
\text { with the } \\
\text { opportunity to }\end{array}$ \\
\hline
\end{tabular}


Cristina Gabriela COSMULESE | Lumen Proceedings 11 | GEKoS2020

\begin{tabular}{|c|c|c|c|c|}
\hline Authors & $\begin{array}{l}\text { Research } \\
\text { purpose }\end{array}$ & Sample & Findings & Utility \\
\hline & $\begin{array}{l}\text { (ICD) set out in } \\
\text { IR is related with } \\
\text { companys' } \\
\text { performance. }\end{array}$ & & $\begin{array}{l}\text { intellectual } \\
\text { capital see to } \\
\text { exposure a } \\
\text { more } \\
\text { optimistic tone } \\
\text { in contrast to } \\
\text { other } \\
\text { companies, } \\
\text { which are } \\
\text { solidary with } \\
\text { signalling } \\
\text { theory }\end{array}$ & $\begin{array}{l}\text { benefit from } \\
\text { more precise } \\
\text { forecasts of } \\
\text { future } \\
\text { performance, } \\
\text { their decisions } \\
\text { being influenced } \\
\text { by the fact that } \\
\text { managers adopt } \\
\text { different } \\
\text { disclosure } \\
\text { strategies } \\
\text { regarding } \\
\text { different types of } \\
\text { company } \\
\text { performance. }\end{array}$ \\
\hline $\begin{array}{l}\text { Gerwanski, } \\
\text { Kordsachia, } \\
\& \text { Velte [16] }\end{array}$ & $\begin{array}{l}\text { The results of } \\
\text { the study } \\
\text { investigates } \\
\text { determinants of } \\
\text { materiality } \\
\text { disclosure } \\
\text { quality (MDQ) } \\
\text { in IR in an } \\
\text { international } \\
\text { setting. }\end{array}$ & $\begin{array}{l}359 \text { entities-year } \\
\text { observations } \\
\text { between } 2013 \\
\text { and } 2016 .\end{array}$ & $\begin{array}{l}\text { Results show } \\
\text { that the IR } \\
\text { legibility, for } \\
\text { the listed firms } \\
\text { on the Dow } \\
\text { Jones } \\
\text { Sustainability } \\
\text { Index, and } \\
\text { earnings } \\
\text { management } \\
\text { do not } \\
\text { influence } \\
\text { MDQ. }\end{array}$ & $\begin{array}{l}\text { The results } \\
\text { contribute to the } \\
\text { ongoing debate } \\
\text { regarding the } \\
\text { need for a } \\
\text { distinctive } \\
\text { assurance } \\
\text { standard for IR. }\end{array}$ \\
\hline $\begin{array}{l}\text { Kulıç \& Kuzey } \\
{[17]}\end{array}$ & $\begin{array}{l}\text { The study } \\
\text { explores the } \\
\text { nature and } \\
\text { extent of } \\
\text { forward-looking } \\
\text { divulgations in } \\
\text { early examples } \\
\text { of IR and } \\
\text { investigates the } \\
\text { determinants of } \\
\text { those } \\
\text { divulgations. }\end{array}$ & $\begin{array}{l}55 \text { non-financial } \\
\text { companies for } \\
\text { the year } 2014 .\end{array}$ & $\begin{array}{l}\text { The findings } \\
\text { showed that } \\
\text { leverage is } \\
\text { negatively } \\
\text { bound to } \\
\text { forward- } \\
\text { looking } \\
\text { divulgations } \\
\text { and gender } \\
\text { diversity, while } \\
\text { firm size are } \\
\text { positively } \\
\text { related }\end{array}$ & $\begin{array}{l}\text { This study } \\
\text { contributes to } \\
\text { the current } \\
\text { literature by } \\
\text { investigating the } \\
\text { determinant } \\
\text { factor of } \\
\text { forward-looking } \\
\text { disclosures. }\end{array}$ \\
\hline
\end{tabular}


Cristina Gabriela COSMULESE | Lumen Proceedings 11 | GEKoS2020

\begin{tabular}{|l|l|l|l|l|}
\hline Authors & $\begin{array}{l}\text { Research } \\
\text { purpose }\end{array}$ & Sample & Findings & Utility \\
\hline $\begin{array}{l}\text { García- } \\
\text { Sánchez, \& } \\
\text { Noguera- } \\
\text { Gámez [18] }\end{array}$ & $\begin{array}{l}\text { This study } \\
\text { analyse the } \\
\text { impact that the } \\
\text { exposure of } \\
\text { integrated } \\
\text { information has } \\
\text { on the cost of } \\
\text { capital }\end{array}$ & $\begin{array}{l}\text { 995 entities } \\
\text { from 27 } \\
\text { countries } \\
\text { between 2009 } \\
\text { and 2013. }\end{array}$ & $\begin{array}{l}\text { The findings } \\
\text { reveal that a } \\
\text { negative } \\
\text { connection } \\
\text { exists between } \\
\text { the cost of } \\
\text { capital and the } \\
\text { disclosure of } \\
\text { an IR }\end{array}$ & $\begin{array}{l}\text { The study is } \\
\text { investors to assist } \\
\text { them in } \\
\text { evaluating the } \\
\text { information } \\
\text { provided by } \\
\text { companies in } \\
\text { their divulgation } \\
\text { policies and in } \\
\text { the precision of } \\
\text { that information }\end{array}$ \\
\hline $\begin{array}{l}\text { García- } \\
\text { Sánchez, \& } \\
\text { Noguera- } \\
\text { Gámez [19] }\end{array}$ & $\begin{array}{l}\text { The study } \\
\text { examines the } \\
\text { possible } \\
\text { connection } \\
\text { between } \\
\text { integrated } \\
\text { information } \\
\text { divulgation and } \\
\text { the degree of } \\
\text { information } \\
\text { asymmetry. }\end{array}$ & $\begin{array}{l}\text { 995 firms from } \\
27 \text { countries } \\
\text { between 2009 } \\
\text { and 2013. }\end{array}$ & $\begin{array}{l}\text { The findings } \\
\text { revel that exist } \\
\text { "a negative } \\
\text { connection } \\
\text { between } \\
\text { information } \\
\text { asymmetry and } \\
\text { the disclosure } \\
\text { of an IR }\end{array}$ & $\begin{array}{l}\text { Reful in } \\
\text { corporate } \\
\text { decision making } \\
\text { and to provide } \\
\text { information to } \\
\text { investors and } \\
\text { stakeholders. }\end{array}$ \\
\hline
\end{tabular}

Source: Author compilation

The specialized literature in this field, at present, is laborious, finding the existence of a significant number of scientific works both internationally and internally. In support of these statements, I note that the samples included in the studies vary greatly. The number of subjects included in the samples is between 55 and 1449 the maximum number of companies and some articles refer mostly to companies in Europe or South Africa, but there are also studies that include companies from around the world. The main source of data collection on companies found in several studies was the IIRC database.

Vitolla et al. [20] show that studies from the first years of integrated reporting are presented more from a normative perspective and focus on the limitations or benefits related to this practice. 


\section{Conclusions}

The evolution of the worldwide economy has changed the way organizations compete among themselves. This is the result of the fact that within the present day globalized context, companies have to face a series of growing changes. Nowadays, the stakeholders are focussed on the social and environment issues such as the protection of the human rights, the fight against poverty and the preservation of the natural ecosystem. All these facts make the companies they interact with to change their objectives, their strategies and their way of implementing them in order to satisfy the demand of the involved tertiary parts. Consequently, as the present study shows, the companies, based on the specific market they operate in, have the chance to adhere to the Integrated Reporting on a voluntary basis, that is to a single document that comprises all those ethical, social and environmental information on their mission, vision, strategy, business model, initiatives and projects are justified to communicate all types of stakeholders those information regarding the overall performance, the added value and the company's brief and transparent layout.One can notice the fact that the IR requires the management to explain the complexity of the connections that exist between the information and the key financial and non-financial indicators that are sometimes either unclear or hidden by emphasizing the relationships among the traditional and operational objectives and the sustainability ones.

\section{Acknowledgment}

"This work is supported by project POCU 125040, entitled "Development of the tertiary university education to support the economic growth PROGRESSIO", co-financed by the European Social Fund under the Human Capital Operational Program 2014-2020.”

\section{References}

[1] Socoliuc M, Grosu V, Hlaciuc, E, Stanciu, Analysis of social responsibility and reporting methods of Romanian companies in the countries of the European Union. Sustainability, 2018, 10 (12): 4662.

[2] Ciubotariu M, Socoliuc M, Mihaila S, Savchuk D. Companies Image: Marketing and Financial Communications; 2019, 3, pp. 223-241

[3] Grosu, M, Mardiros, D-N, Dicu RM. Corporate social responsibility and its influence on human capital in the SMEs from EU's emerging economies, The 
17th IBIMA conference on Creating Global Competitive Economies; 2011, 360, 17, 1676-1686.

[4] GRI 102: General Disclosures 2016. In Consolidated set of GRI Sustainability Reporting Standards; 2018. Available from: https://www.globalreporting.org/standards/gri-standards-downloadcenter/consolidated-set-of-gri-standards/

[5] G4 Sustainability Reporting Guidelines. Part 1: Reporting principles and standard disclosures; 2013. Retrieved from: https://www.globalreporting.org/resourcelibrary/GRIG4-Part1-ReportingPrinciples-and-Standard-Disclosures.pdf.

[6] Mates D, Bostan I, Socoliuc M, Grosu, V. (The Importance Of The Accounting Information In The Process Of Communication, Analele UEMRZEC. Editie specială, An VI; 2008.

[7] Socoliuc, M, Grosu V. Financial instruments evaluation and the difficulties of economic and financial communication, Annals of the „Constantin Brâncuşi” University of Târgu Jiu, Economy Series, 2015, 2: 226-230.

[8] Farné S. Qualità sostenibile: strategie e strumenti per creare valore, competere responsabilmente e ottenere successo duraturo: le norme ISO 26000, SA 8000, ISO 9004, ISO 14000. FrancoAngeli; 2012.

[9] Onida, P. L’Azienda. Primi principi di gestione e di organizzazione. Milano: Giuffré; 1954.

[10] Melis V. Imprese al test di sostenibilità. Economia; 2017. Available from: https://www.ilsole24ore.com/art/imprese-test-sostenibilita-

AEMWZ1fB?refresh_ce=1.

[11] Gasperini A. Il vero bilancio integrato. Storie di creazione del valore a breve, medio e lungo termine. Milano: Ipsoa; 2013.

[12] PricewaterhouseCoopers (PWC) Bilancio integrato, 2014. Available from: https://www.pwc.com/it/it/publications/assets/docs/bilancio-integrato.pdf.

[13] Cosmulese CG, Socoliuc M, Ciubotariu MS., Mihaila S, Grosu V. An empirical analysis of stakeholders' expectations and integrated reporting quality. Economic research, 2019, 32(1): 3963-3986.

[14] Roman, AG., Mocanu M, Hoinaru, R. Disclosure style and its determinants in integrated reports. Sustainability; 2019, 11(7).

[15] Beretta, V, Demartini C, Trucco, S. Does environmental, social and governance performance influence intellectual capital disclosure tone in integrated reporting?", Journal of Intellectual Capital. 2019; 20(1): 100-124. Available from: https://doi.org/10.1108/JIC-02-2018-0049.

[16] Gerwanski J, Kordsachia O, Velte P. Determinants of materiality disclosure quality in integrated reporting: Empirical evidence from an international setting. Business Strategy and the Environment. 2019; 28(5): 750-770.

[17] Kıliç M, Kuzey C. Determinants of forward-looking disclosures in integrated reporting", Managerial Auditing Journal. 2018; 33(1): 115-144. Available from. https://doi.org/10.1108/MAJ-12-2016-1498. 
[18] García-Sánchez IM, Noguera-Gámez L. Integrated reporting and stakeholder engagement: The effect on information asymmetry. Corporate Social Responsibility and Environmental Management. 2017; 24(5): 395-413.

[19] García-Sánchez IM, Noguera-Gámez L. Integrated Reporting and Stakeholder Engagement: The Effect on Information Asymmetry. Corporate Social Responsibility and Environmental Management. 2016; 24(5): 395-413. Retrieved from: https://doi.org/10.1002/csr.1415.

[20] Vitolla F, Raimo N, Rubino M. Appreciations, criticisms, determinants, and effects of integrated reporting: A systematic literature review. Corporate Social Responsibility and Environmental Management. 2019; 26(2): 518-528. 